9PRXM

Gernal Profesi Kesehatan Masyarakat

http://jurnal.bhmm.ac.id/index.php/jpkm

${ }^{\triangle}$ Corresponding Author.

email address : mkepfitria@gmail.com

Received : 19 Juli 2021 Revised : 23 Agustus 2021 Accepted : 14 Oktober 2021

\title{
Pengaruh Pendidikan Kesehatan Range of Motion (ROM) terhadap Pengetahuan dalam Merawat Ulkus Kaki Diabetik pada Pasien Diabetes Mellitus di RSUD Dr. Soeroto Ngawi
}

\author{
${ }^{\square}$ Fitria Yuliana \& Sesaria Betty Mulyati \\ Program Studi Keperawatan, Stikes Bhakti Husada Mulia Madiun, Indonesia
}

\begin{abstract}
ABSTRAK
Penelitian ini menggunakan metode penelitian kuantitatif dengan jenis penelitian PreExperimental, dan dengan rancangan one group pre-Test and post-Test. Sampel dalam penelitian ini sejumlah 19 responden. Analisa data yang digunakan adalah analisa univariat dan bivariat menggunakan ilcoxon signed rank test. Dari 19 responden dapat diketahui bahwa sebelum dilakukan pendidikan kesehatan sebagian besar memiliki pengetahuan yang kurang tentang Range Of Motion (ROM) sejumlah 14 orang $(73,7 \%)$ dan yang terkecil sejumlah 2 orang (10,5\%) memiliki pengetahuan yang baik tentang Range Of Motion (ROM). dari 19 responden dapat diketahui bahwa setelah dilakukan pendidikan kesehatan, sebagian besar memiliki pengetahuan yang baik tentang Range Of Motion (ROM) sejumlah 12 orang $(63,2 \%)$, sedangkan yang terkecil sejumlah 2 orang $(10,5 \%)$ memiliki pengetahuan yang kurang tentang Range Of Motion (ROM). didapatkan hasil uji Wilcoxon signed rank test didapatkan nilai $p$ value $=0,001<a=0,05 \mathrm{H1}$ diterima artinya ada pengaruh pendidikan kesehatan terhadap pengetahuan tentang Range Of Motion (ROM) pada Pasien Ulkus Diabetik di Ruang Seruni dan Ruang Anggrek RSUD dr. Soeroto Ngawi.
\end{abstract}

Kata kunci: Pendidikan Kesehatan, Range of Motion (ROM), Merawat Ulkus Kaki, Diabetik.

The Effect of Range of Motion (ROM) Health Education on Knowledge in Treating Diabetic Foot Ulcus in Diabetes Mellitus Patients in RSUD Dr. Soeroto Ngawi

\begin{abstract}
This study uses a quantitative research method with the type of Pre-Experimental research, and with a one group pre-Test and post-Test design. The sample in this study were 19 respondents. The data analysis used was univariate and bivariate analysis using the Ilcoxon signed rank test. From 19 respondents, it can be seen that before health education was carried out, most of them had less knowledge about Range Of Motion (ROM) as many as 14 people (73.7\%) and the smallest number of 2 people (10.5\%) had good knowledge about Range of Motion (ROM). Of Motion (ROM). From 19 respondents it can be seen that after health education, most have good knowledge about Range Of Motion (ROM) as many as 12 people (63.2\%), while the smallest number of 2 people (10.5\%) have less knowledge about Range Of Motion (ROM). Wilcoxon signed rank test results obtained p value $=0.001<a=0.05 \mathrm{H1}$ is accepted meaning that there is an effect of health education on knowledge about Range Of Motion (ROM) in Diabetic Ulcer Patients in Seruni Room and Orchid Room RSUD dr. Soeroto Ngawi.
\end{abstract}

Kata kunci: Health Education, Range of Motion (ROM), Treating Foot Ulcers, Diabetic.

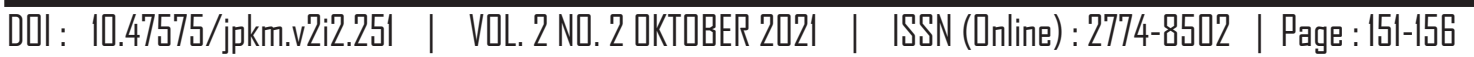




\section{PENDAHULUAN}

Menurut WHO memprediksi kenaikan jumlah penyandang DM di Indonesia dari 8,4 juta pada tahun 2000 menjadi sekitar 21,3 juta pada tahun 2030 .

China, India, Amerika Serikat, Brazil, dan Meksiko dengan jumlah estimasi orang dengan DM sebesar 10 juta (IDF, 2017). Sedangkan menurut IDF (2019) sekitar 468 juta orang dewasa (20-79 tahun) hidup dengan diabetes, pada 2045 ini akan meningkat menjadi 700 juta, dan 4,2 juta diabetes menyebabkan kematian. Berdasarkan data RISKESDAS (2018), prevalensi tertinggi DM di Jawa adalah provinsi DKI Jakarta dengan jumlah 2,5\% pada 2013 kemudian pada tahun 2018 meningkat menjadi 3,4\%, provinsi JawaTimur 2,1\% pada 2013 dan meningkat menjadi 2,6\% pada tahun 2018, provinsi Jawa Tengah 1,6\% pada 2013 dan meningkat menjadi 2,1\% pada 2018, provinsi D.I.Yogyakarta 2,6\% pada 2013 dan meningkat menjadi 3,0\% pada 2018, di provinsi Jawa Barat 1,3\% pada tahun 2013 dan meningkat menjadi 1,8\%.

Berdasarkan data dari RSUD dr. Soeroto Ngawi jumlah kunjungan pasien DM pada tahun 2015 sejumlah 9.203 orang, kunjungan pasien DM pada tahun 2016 sejumlah 12.213 orang dan kunjungan pasien DM pada tahun 2017 sejumlah 14.784 orang.Jumlah pasien DM dengan Ulkus Diabetik pada bulan November 2018 - Januari 2019 sejumlah 31 pasien (Riskhy, 2019). Sedangkan pada bulan September-november 2019 jumlah pasien DM di Ruang Seruni, Anggrek dan Dahlia sejumlah 108 pasien, sedangkan jumlah pasien ulkus diabetik yaitu sejumlah 64 pasien. Dari data-data tersebut jika ditarik kesimpulan bahwa penyakit Diabetes Mellitus dan yang mengalami komplikasi ulkus diabetik mengalami peningkatan.

\section{METODE PENELITIAN}

Jenis Penelitian ini menggunakan metode penelitian kuantitatif dengan jenis penelitian PreExperimental, dan dengan rancangan one group pre-Test and post-Test. Populasi dalam penelitian ini adalah responden Diabetes Mellitus dengan kaki ulkus diabetik di RSUD dr. Soeroto Ngawi dalam bulan SeptemberNovember 2020 rata-rata setiap bulannya 22 responden. sampel akhir yang dibutuhkan dalam penelitian ini adalah 18 responden 2 sebagai Drop Out. Analisa yang digunakan pada penelitian ini menggunakan uji non parametric yaitu uji wilcoxon.

\section{HASIL DAN PEMBAHASAN \\ Karakteristik}

Dari 19 responden dapat diketahui bahwa sebelum dilakukan pendidikan kesehatan sebagian besar memiliki pengetahuan yang kurang tentang Range Of Motion (ROM) sejumlah 14 orang $(73,7 \%)$ dan yang terkecil sejumlah 2 orang $(10,5 \%)$ memiliki pengetahuan yang baik tentang Range $O f$ Motion (ROM).

Dari 19 responden dapat diketahui bahwa setelah dilakukan pendidikan kesehatan, sebagian besar memiliki pengetahuan yang baik tentang Range of Motion (ROM) sejumlah 12 orang $(63,2 \%)$, sedangkan yang terkecil sejumlah 2 orang $(10,5 \%)$ memiliki pengetahuan yang kurang tentang Range $O f$ Motion (ROM).

Hasil uji Wilcoxon signed rank test didapatkan nilai $p$ value $=0,001<\mathrm{a}=0,05 \mathrm{H} 1$ diterima artinya ada pengaruh pendidikan kesehatan terhadap pengetahuan tentang Range Of Motion (ROM) pada Pasien Ulkus Diabetik di Ruang Seruni dan Ruang Anggrek RSUD dr. Soeroto Ngawi.

\section{PEMBAHASAN}

Pengetahuan Pasien Ulkus Kaki Diabetik sebelum Dilakukan Pendidikan Kesehatan Tentang Range Of Motion (ROM) di Ruang seruni dan Ruang Anggrek RSUD Kota Madiun.

Dari 19 Pasien Ulkus Diabetes dapat diketahui bahwa sebelum dilakukan pendidikan kesehatan sebagaian besar yaitu 14 orang $(73,7 \%)$ memiliki pengetahuan yang kurang tentang latihan gerak kaki. Hasil analisis Test menunjukkan bahwa sebagian besar responden yang tidak mengetahui tentang pengertian latihan gerak kaki sejumlah 16 orang $(84,2 \%)$, tidak mengetahui waktu melakukan latihan gerak kaki 12 orang $(63,2 \%)$,tidak mengetahui langkah-langkah melakukan latihan gerak kaki $11 \operatorname{orang}(57,9 \%)$. 
Tabel 1

Distribusi Frekuensi Karakteristik Responden

\begin{tabular}{clcccc}
\hline No & Variable & F & $\%$ & Total & $\%$ \\
\hline 1 & Usia (tahun) & & & & \\
& $36-45$ & 1 & 5,3 & & \\
& $46-55$ & 5 & 26,3 & 19 & $100 \%$ \\
& $56-65$ & 11 & 57,9 & & \\
\multirow{2}{*}{2} & $66>$ & 2 & 10,5 & & \\
& Jenis Kelamin & & & & \\
& Laki-laiki & 4 & 21,1 & & \\
\multirow{2}{*}{3} & Perempuan & 15 & 78,9 & 19 & $100 \%$ \\
& Pendidikan & & & & \\
& SD & 8 & 42,1 & & \\
& SMP & 6 & 31,6 & 19 & \\
& SMA & 5 & 26,3 & & \\
\hline
\end{tabular}

Sumber: Data Diolah

Tabel 2

Pengetahuan Tentang Range of Motion (ROM) pada Responden Sebelum Dilakukan Pendidikan Kesehatan

\begin{tabular}{clcc}
\hline No & Pengetahuan & Frekuensi (f) & Persentase (\%) \\
\hline 1 & Kurang & 14 & 73,7 \\
2 & Cukup & 3 & 15,8 \\
3 & Baik & 2 & 10,5 \\
& Jumlah & 19 & 100 \\
\hline
\end{tabular}

Sumber: Data Diolah

Tabel 3

Pengetahuan Tentang Range Of Motion (ROM) Pada Responden Sesudah Dilakukan

Pendidikan Kesehatan

\begin{tabular}{clcc}
\hline No & Pengetahuan & Frekuensi (f) & Persentase (\%) \\
\hline 1 & Kurang & 2 & 10,5 \\
2 & Cukup & 5 & 26,3 \\
3 & Baik & 12 & 63,2 \\
& Jumlah & 19 & 100 \\
\hline
\end{tabular}

Sumber: Data Diolah

Pengetahuan seseorang dipengaruhi oleh beberapa faktor diantaranya pemberian pendidikan kesehatan, informasi atau media massa, dari aspek sosial, aspek budaya, aspek ekonomi, dari pengalaman dan Usia (Budiman \& Riyanto, 2014). Teori ini juga dibuktikan oleh hasil analisis wawancara dengan responden bahwa yang memiliki pengetahuan cukup dan baik sebelumnya pernah mendapatkan informasi tentang latihan gerak kakiyang diperoleh dari internet dan tenaga medis. Usia juga menentukan pengetahuan seseorang,

hasil penelitian menunjukkan pada usia 35-60 tahun sebagian memiliki pengetahuan yang cukup dan baik, sedangkan pada usia $61>$ tahun hanya memiliki pengetahuan yang kurang. Lansia akan mengalami perubahan kognitif, afektif, dan psikomotor (Cristensen, 2006). Karena adanya perubahan kognitif, afektif dan psikomotor pada lansia sehingga semakin bertambahnya usiarasa ingin tahu untuk mencari nformasi, untuk menerima informasi dan memecahkan masalah atau penyakit yang dialaminya menjadi berkurang. 
Tabel 4

Pengaruh Pendidikan Kesehatan terhadap Pengetahuan Tentang Range Of Motion (ROM)

\begin{tabular}{cccc}
\hline Pengetahuan & Wilcoxon & Alpha (a) & Mean \\
\hline Pretest & & & 0,39 \\
Posttest & 0,001 & 0,05 & 1,50 \\
\hline
\end{tabular}

Sumber: Data Diolah

Pengetahuan tentang kesehatan dapat diperoleh dari pendidikan formal dan nonformal, semakin banyak informasi semakin banyak juga pengetahuan yang didapat tentang kesehatan (Budiman dan Riyanto, 2013). Dari segi pendidikan perlu ditekankan bahwa seseorang yang berpendidikan tinggi belum tentu memiliki pengetahuan tentang latihan gerak kaki dan begitupun sebaliknya, karena untuk mendapat informasi tentang kesehatan tidak hanya bisa didapat dari pendidikan formal saja namun juga dari berbagai sumber. Hasil analisis penelitian menunjukan bahwa 4 responden yang berpendidikan Tamat Pendidikan Menengah Atas memiliki pengetahuan yang kurang, sedangkan beberapa responden yang berpendidikan dibawahnya sebagian memiliki pengetahuan yang cukup maupun baik, karena pada saat menempuh pendidikan tidak diajarkan tentang latihan gerak kaki.

Penatalaksanaan mandiri termasuk latihan gerak kaki tidak dapat diketahui seseorang jika tidak mendapatkan informasi atau mencari informasi sendiri, selain itu pendidikan latihan gerak kaki juga masih jarang sekali diliput dimedia massa.

Pengetahuan Pasien Ulkus Kaki Diabetik sesudah Dilakukan Pendidikan Kesehatan Tentang Range of Motion (ROM) di Ruang seruni dan Ruang Anggrek RSUD Kota Madiun.

Dari 19 Pasien Ulkus Diabetes dapat diketahui bahwa sesudah dilakukan pendidikan kesehatan sebagian besar yaitu 12 orang $(63,2 \%)$ memiliki pengetahuan yang baik tentang Range Of Motion (ROM). Dari hasil tabulasi test menunjukkan responden yang mengetahui pengertian tentang Range of Motion (ROM) sebanyak 10 orang $(52,6 \%)$, mengetahui waktu pelaksanaan ROM 19 orang $(100 \%)$, dan yang mengetahui tentang langkah-langkah ROM sebanyak 15 orang $(79 \%)$.
Informasi yang diperoleh baik dari pendidikan formal maupun nonformal dapat memberikan pengaruh jangka pendek sehingga menghasilkan perubahan atau peningkatan pengetahuan (Budiman \& Riyanto, 2013).

Penurunan psikomotor dapat dilihat dari keterbatasan lansia menganalisa informasi, mengambil keputusan, serta melakukan suatu tindakan (Nugroho, 2000). Hasil analisis penelitian menunjukkan bahwa pengetahuan pada sebagian besar responden mengalami peningkatan, namun masih terdapat 2 responden yang tidak mengalami peningkatan setelah dilakukan pendidikan kesehatan. Hal ini terjadi pada responden yang berusia 60 tahun keatas.

Lingkungan sangat berpengaruh terhadap proses masuknya pengetahuan dalam individu (Budiman dan Riyanto, 2013). Hal ini terjadi karena adanya timbal balik lingkungan dan proses masuknya pengetahuan, semakin kondusif lingkungan semakin baik pula proses masuknya pengetahuan (Salafiah, 2014). Hasil analisis penelitian menunjukkan bahwa setiap responden memiliki perubahan pengetahuan yang berbeda ada yang dari kategori kurang menjadi cukup, dari kategori kurang menjadi baik, dsb. Perubahan yang berbeda ini karena pada saat diberikan pendidikan kesehatan beberapa keluarga responden ikut bertanya kepada peneliti dan beberapa keluarga pasien lain yang dalam satu ruangan juga ikut melihat proses pemberian pendidikan kesehatan pada responden, sehingga kefokusan responden terbagi karena lingkungannya yang kurang tenang.

Sebagai sarana komunikasi berbagai bentuk media massa seperti televise, radio, surat kabar, majalah, leaflet dan lainlain mempunyai pengaruh besar dalam pembentukan opini orang dan kepercayaan orang (Budiman \& Riyanto, 2013). Pendidikan kesehatan dilakukan dengan metode ceramah, dan demonstrasi untuk yang kurang memahami dengan intruksi yang diberikan oleh peneliti. 
Peneliti menggunakan media leaflet, sehingga akan mempermudah responden untuk menerima dan memahami informasi yang diberikan.Hasil analisis penelitian tidak menunjukkan adanya penurunan pengetahuan atau penurunan jumlah nilai pada Test responden.

Pengaruh Pendidikan Kesehatan Tentang Range of Motion (ROM) dalam merawat Ulkus Kaki Diabetik di Ruang seruni dan Ruang Anggrek RSUD Kota Madiun.

Berdasarkan hasil penelitian ini, dengan menggunakan analisis wilcoxon signed rank testmenunjukkan hasil uji statistic di dapatkan nilai $p=0,001<\mathrm{a}=0,05$ yang berarti bahwa $\mathrm{H} 0$ ditolak dan $\mathrm{H} 1$ diterima yang artinya ada pengaruh pendidikan kesehatan terhadap pengetahuan tentang Range Of Motion (ROM) pada responden di Ruang Seruni dan Ruang Anggrek RSUD dr. Soeroto Ngawi.

Dalam waktu yang pendek pendidikan kesehatan akan menghasilkan perubahan atau peningkatan pengetahuan masyarakat (Notoatmodjo, 2011 dalam widodo, 2017). Pengetahuan merupakan hasil dari tahu, terjadi setelah orang melakukan pengindraan terhadap suatu objek tertentu (Notoatmodjo dalam Budiman, 2013).Pendidikan merupakan usaha untuk mengembangkan kepribadian dan kemampuan seseorang.Pendidikan kesehatan adalah suatu penerapan konsep pendidikan dalam bidang kesehatan. Sesorang dapat dikatakan belajar apabila dalam dirinya terjadi perubahan, dari tidak tahu menjadi tahu (Notoatmodjo, 2010). Teori ini dibuktikan juga dengan hasil analisis pengetahuan Pre Test dan Post Test yang memberikan hasil bahwaterdapat perubahan nilai pengetahuan responden.

Teori dan penelitian ini juga dikuatkan dengan hasil peneliti lainnya tentang Pengaruh pendidikan kesehatan SADARI terhadap pengetahuan pada Ibu-ibu PKK yang dilakukan oleh Valentine (2018) yang memberikan hasil $p=0,000<a=0,05$ yang berarti terdapat pengaruh. Penelitian Widodo (2017) Pengaruh Health Education
Terhadap Pengetahuan Masyarakat penderita Hipertensi Tentang Penyakit Jantung Koroner Di Puskesmas Geger Kabupaten Madiun juga memberikan hasil $p=0,000<a=0,05$ yang berarti terdapat pengaruh. Kedua penelitian ini memiliki kesamaan bahwa pendidikan kesehatan dapat mempengaruhi pengetahuan seseorang.

\section{SIMPULAN}

Pengetahuan Pasien Ulkus Diabetik sebelum dilakukan pendidikan kesehatan Range of Motion (ROM), sebagian besar 14 orang (73,7\%) memiliki pengetahuan yang kurang. Pengetahuan Pasien Ulkus Diabetik sesudah dilakukan pendidikan kesehatan Range of Motion (ROM), sebagian besar 12 orang $(63,2 \%)$ memiliki pengetahuan yang baik. Ada pengaruh pendidikan kesehatan terhadap pengetahuan tentang Range of Motion (ROM) pada pasien Ulkus Diabetik di Ruang Seruni dan Ruang Anggrek RSUD dr. Soeroto Ngawi. Hasil tersebut berdasarkan uji Wilcoxon signed rank test dengan $p$ value $=0,001<a$ $=0,05$ maka $H 1$ diterima. Peneliti selanjutnya diharapkan dapat mengembangkan penelitian serupa dengan pengembangan penelitian lebih lanjut seperti dengan menggunakan metode pendidikan kesehatan yang berbeda. Menggunakan metode pendidikan kesehatan dengan demonstrasi mungkin lebih memberikan pengaruh yang baik, karena pada saat penelitian dengan metode ini responden sedikit mengalami kesulitan untuk menerima informasi.

\section{DAFTAR PUSTAKA}

Budiman dan Riyanto Agus. (2014). Kapita Selekta Kuesioner Pengetahuan dan Sikap dalam Penelitian Kesehatan. Jakarta : Salemba Medika.

Cristensen, kockrow. (2006). Adult Health Nursing Fifth Edition. Philadaphia : Mosby Company.

Damayanti, Santi. (2015). Diabetes Mellitus dan Penatalaksanaan Keperawatan. Yogyakarta : Pinang Merah. 
156 Fitria Yuliana \& Sesaria Betty Mulyati, Pengaruh Pendidikan Kesehatan Range of Motion (ROM)

IDF. (2017). Edition Of The IDF Diabetes Atlas 2017.http://Fmdiabetes.org.

. (2019). Fakta dan Angka Diabetes Mellitus International Diabetes Federation. http://Idf.org.

Notoatmodjo, Soekidjo. (2012). Metodologi Penelitian Kesehatan. Jakarta : Rineka Cipta.

(2010). Promosi Kesehatan Teori dan Aplikasi. Jakarta : Rineka Cipta.

Nurhayati, Desy. (2018). Pengaruh Latihan Range Of Motion (ROM) Terhadap Activity Daily Living (ADL) Pasien Post Stroke di Desa Pitu Kecamatan Pitu Kabupaten Ngawi.Skripsi, Sekolah Tinggi Ilmu Kesehatan “BHM”, Madiun.
RISKESDAS. (2018). Laporan Nasional Riset Kesehatan Dasar. Jakarta : LPB Penelitian dan Pengembangan Kesehatan.

Salafiah, Nurul. (2014). Pengaruh Pendidikan Kesehatan terhadap Pengetahuan \& Sikap Ibu tentang Pola Asuh Anak Usia Bayi (Infant) di Wilayah Kerja Puskesmas Kartasura. https://Eprints. ums.ac.id.

Widodo, Lantip. (2017). Health Education terhadap tingkat pengetahuan Masyarakat Penderita Hipertensi tentang Penyakit Jantung Koroner di Puskesmas Geger Kabupaten Madiun. http://Repository.stikes.bhm.ac.id. 